\title{
Mechanism of orthophosphate (PO4-P) adsorption onto different biochars
}

Eduah, Joseph Osafo; Nartey, Eric Kwesi; Abekoe, Mark Kofi; Henriksen, Stephan Weck; Andersen, Mathias Neumann

Published in:

Environmental Technology and Innovation

DOI:

10.1016/j.eti.2019.100572

Publication date:

2020

Document version

Publisher's PDF, also known as Version of record

Document license:

CC BY

Citation for published version (APA):

Eduah, J. O., Nartey, E. K., Abekoe, M. K., Henriksen, S. W., \& Andersen, M. N. (2020). Mechanism of orthophosphate $(\mathrm{PO}-\mathrm{P})$ adsorption onto different biochars. Environmental Technology and Innovation, 17, [100572]. https://doi.org/10.1016/j.eti.2019.100572 


\title{
Mechanism of orthophosphate $\left(\mathrm{PO}_{4}-\mathrm{P}\right)$ adsorption onto different biochars
}

\author{
Joseph Osafo Eduah a,b, Eric Kwesi Nartey a,*, Mark Kofi Abekoe ${ }^{\mathrm{a}}$, \\ Stephan Weck Henriksen ${ }^{b}$, Mathias Neumann Andersen ${ }^{\mathrm{c}}$ \\ a Department of Soil Science, School of Agriculture, University of Ghana, P. O. Box LG 245, Legon, Ghana \\ ${ }^{\mathrm{b}}$ Department of Geosciences and Natural Resource Management, University of Copenhagen, Øster Voldgade \\ 10, 1350, Copenhagen, Denmark \\ c Department of Agroecology and Environment, Aarhus University, Denmark
}

\section{A R T I C L E I N F O}

\section{Article history:}

Received 8 May 2019

Received in revised form 28 November 2019

Accepted 30 November 2019

Available online 4 December 2019

\section{Keywords:}

Biochar

Phosphate

Adsorption mechanism

Models

\begin{abstract}
A B S T R A C T
The adsorption mechanisms of phosphate $\left(\mathrm{PO}_{4}-\mathrm{P}\right)$ onto cocoa pod husk (CP), corn cob $(\mathrm{CC})$, rice husk (RH) and palm kernel shell (PK) biochar pyrolyzed at $300{ }^{\circ} \mathrm{C}$ and $650{ }^{\circ} \mathrm{C}$ were investigated. A series of batch experiments were undertaken to assess the effects of contact time and $\mathrm{pH}$. Results show that $\mathrm{PO}_{4}-\mathrm{P}$ adsorption equilibria for the biochar types was within 6-15 h, being rapid in the $300{ }^{\circ} \mathrm{C}$-biochar types. The equilibrium $\mathrm{pH}$ for maximum $\mathrm{PO}_{4}-\mathrm{P}$ adsorption varied among biochar types, ranging from of 2.6 to 4.8 and increasing with decreasing $\mathrm{PO}_{4}-\mathrm{P}$ adsorption. Pseudo-secondorder and Elovich models explained the adsorption data well indicating a chemisorption process on heterogeneous biochar surface. $\mathrm{PO}_{4}-\mathrm{P}$ adsorption was controlled initially by intraparticle diffusion and subsequently by chemisorption. Per the properties of the biochars (FTIR and elemental composition) and $\mathrm{pH}$ (equilibrium $\mathrm{pH}$ and $\Delta \mathrm{pH}$ ), $\mathrm{PO}_{4}-\mathrm{P}$ was adsorbed through electrostatic attraction, surface precipitation and ligand exchange, and the relative importance of these processes differed among the biochar types. Biochar types (PK300, PK650, CP300, CP650, RH650 and CC650) that adsorbed $\mathrm{PO}_{4}-\mathrm{P}$ through surface precipitation and ligand exchange reactions can be used to remove $\mathrm{PO}_{4}-\mathrm{P}$ from wastewater since $\mathrm{PO}_{4}-\mathrm{P}$ is strongly adsorbed, controlling $\mathrm{PO}_{4}-\mathrm{P}$ enrichment of water bodies.
\end{abstract}

(C) 2019 Elsevier B.V. All rights reserved.

\section{Introduction}

Adsorption of phosphate $\left(\mathrm{PO}_{4}-\mathrm{P}\right)$ by organic material is of relevance in controlling the transport, mobility and enrichment of $\mathrm{PO}_{4}-\mathrm{P}$ in aquatic environment. Although $\mathrm{PO}_{4}-\mathrm{P}$ is an essential nutrient for the growth of plants and other living organisms, it can also serve as an environmental pollutant (Dodds et al., 2008; Almeelbi and Bezbaruah, 2012). About $0.02 \mathrm{mg} \mathrm{L}^{-1}$ of dissolved $\mathrm{PO}_{4}-\mathrm{P}$ in water bodies is considered to have potential risk to the proliferation of algal growth (USEPA, 1995). The increased $\mathrm{PO}_{4}-\mathrm{P}$ in water bodies as a result of inappropriate and frequent discharge of waste water stimulates excessive growth of phytoplankton and algae which in turn decrease the quality of drinking water (Dodds et al., 2008). Thus, in order to reduce the negative effects of overloading water bodies with $\mathrm{PO}_{4}$ - $\mathrm{P}$, it is necessary to assess various strategies and to evaluate the $\mathrm{PO}_{4}-\mathrm{P}$ removal effectiveness of adsorbents that could be exploited for use as waste water cleansing agents of $\mathrm{PO}_{4}$-P ions prior to wastewater discharge into natural water bodies (Biswas et al., 2008).

\footnotetext{
* Corresponding author.

E-mail address: enartey@ug.edu.gh (E.K. Nartey).
} 
Table 1

Properties of corn cob biochar, palm kernel shell biochar, cocoa pod husk biochar and rice husk biochar produced at $300{ }^{\circ} \mathrm{C}$ and $650{ }^{\circ} \mathrm{C}$.

\begin{tabular}{|c|c|c|c|c|c|c|c|c|}
\hline \multirow{3}{*}{$\begin{array}{l}\text { Biochar } \\
\text { Temperature } \\
\text { Abbreviation }\end{array}$} & \multicolumn{2}{|c|}{ Cocoa pod husk } & \multicolumn{2}{|c|}{ Rice husk } & \multicolumn{2}{|c|}{ Corn cob } & \multicolumn{2}{|c|}{ Palm kernel shell } \\
\hline & $300{ }^{\circ} \mathrm{C}$ & $650{ }^{\circ} \mathrm{C}$ & $300{ }^{\circ} \mathrm{C}$ & $650{ }^{\circ} \mathrm{C}$ & $300{ }^{\circ} \mathrm{C}$ & $650{ }^{\circ} \mathrm{C}$ & $300{ }^{\circ} \mathrm{C}$ & $650{ }^{\circ} \mathrm{C}$ \\
\hline & СР300 & СР650 & RH300 & RH650 & CC300 & CC650 & PK300 & PK650 \\
\hline $\mathrm{pH}\left(\mathrm{H}_{2} \mathrm{O}\right)$ & 8.50 & 10.21 & 7.11 & 9.50 & 8.90 & 10.30 & 5.51 & 6.70 \\
\hline C (\%) & 57.94 & 61.96 & 41.58 & 42.55 & 72.98 & 78.07 & 81.99 & 89.58 \\
\hline $\mathrm{CEC}\left(\mathrm{cmol}_{+} \mathrm{kg}^{-1}\right)$ & 63.50 & 53.00 & 49.40 & 38.00 & 38.02 & 30.10 & 27.90 & 22.10 \\
\hline Total $\mathrm{P}\left(\mathrm{g} \mathrm{kg}^{-1}\right)$ & 2.45 & 3.16 & 1.19 & 1.52 & 1.54 & 1.94 & 0.17 & 0.25 \\
\hline $\mathrm{Ca}\left(\mathrm{g} \mathrm{kg}^{-1}\right)$ & 9.60 & 11.71 & 2.07 & 3.29 & 3.32 & 4.19 & 1.95 & 2.94 \\
\hline $\operatorname{Mg}\left(\mathrm{g} \mathrm{kg}^{-1}\right)$ & 7.23 & 8.86 & 0.91 & 1.27 & 2.43 & 3.43 & 0.27 & 0.33 \\
\hline $\mathrm{K}\left(\mathrm{g} \mathrm{kg}^{-1}\right)$ & 0.17 & 0.22 & 0.19 & 1.52 & 1.54 & 1.94 & 0.17 & 0.25 \\
\hline $\mathrm{Na}\left(\mathrm{g} \mathrm{kg}^{-1}\right)$ & 41.33 & 58.94 & 5.34 & 8.19 & 24.71 & 30.80 & 0.45 & 0.58 \\
\hline Si $\left(\mathrm{g} \mathrm{kg}^{-1}\right)$ & 8.91 & 28.36 & 138.53 & 194.49 & 13.94 & 14.44 & 9.74 & 14.41 \\
\hline Total $\mathrm{N}\left(\mathrm{g} \mathrm{kg}^{-1}\right)$ & 3.91 & 2.73 & 1.77 & 1.21 & 2.93 & 1.91 & 3.82 & 2.12 \\
\hline $\mathrm{Al}\left(\mathrm{g} \mathrm{kg}^{-1}\right)$ & 0.46 & 0.99 & 1.26 & 1.88 & 0.57 & 1.10 & 1.04 & 2.11 \\
\hline $\mathrm{Fe}\left(\mathrm{g} \mathrm{kg}^{-1}\right)$ & 0.39 & 0.65 & 1.25 & 1.66 & 0.62 & 0.95 & 0.68 & 1.49 \\
\hline Carboxylic $\left(\mathrm{mmol} \mathrm{g}^{-1}\right)$ & 0.55 & 0.09 & 0.38 & 0.10 & 0.47 & 0.06 & 0.21 & 0.05 \\
\hline Phenolic (mmol g $\left.\mathrm{g}^{-1}\right)$ & 1.22 & 0.46 & 1.01 & 0.23 & 0.71 & 0.32 & 1.32 & 0.65 \\
\hline Lactonic $\left(\mathrm{mmol} \mathrm{g}^{-1}\right)$ & 0.27 & 0.03 & 0.19 & 0.00 & 0.11 & 0.04 & 0.08 & 0.00 \\
\hline Total acid group ( $\left.\mathrm{mmol} \mathrm{g}^{-1}\right)$ & 2.12 & 0.94 & 2.04 & 0.60 & 2.10 & 0.97 & 1.82 & 0.80 \\
\hline
\end{tabular}

To treat $\mathrm{PO}_{4}-\mathrm{P}$ contaminated water, a number of technological approaches have been deployed such as electrodialysis, reverse osmosis, chemical precipitation, membrane technologies, biosorption and ion exchange (Demirbas, 2008). The less expensive, technologically and environmentally friendly among the aforementioned methods is biosorption technique, and biochar is a common biosorbent. Biochar is a carbon-rich, fine grained, and porous material. It is usually produced by thermal decomposition of biomass under limited oxygen conditions at temperatures $<850{ }^{\circ} \mathrm{C}$ (Lehmann, 2007). It has gained a lot of attention in recent times not only for its role in soil fertility improvement and carbon sequestration but also as a low-cost adsorbent for wastewater treatment (Yao et al., 2012; Zhang et al., 2016). Reports have indicated that biochar has a strong ability to remove chemical contaminants in water including $\mathrm{PO}_{4}-\mathrm{P}$, organic contaminants and heavy metals (Kasozi et al., 2010; Yao et al. 2013; Zhang et al., 2016). Due to its highly-porous structure, mineral contents (e.g. $\mathrm{CaCO}_{3}$, Fe and $\mathrm{Al}$ ) and functional groups (e.g. phenolic, carboxylic and amino groups), biochar has a high affinity for $\mathrm{PO}_{4}-\mathrm{P}$ (Li et al., 2017). However, the adsorptive properties of biochar depends largely on the feedstock and pyrolysis temperature (Zhao et al., 2013).

Adsorption kinetics expresses the time-dependent removal of adsorbate by an adsorbent in an aqueous solution and its application is relevant for elucidating adsorption mechanism (Wahab et al., 2011; Jung et al., 2015; Zhang et al., 2015). Using chemical adsorption kinetic models (e.g. pseudo-first-order, pseudo-second-order, Elovich and JohnsonMehl-Avrami), the mechanism of $\mathrm{PO}_{4}-\mathrm{P}$ adsorption by biochar has been reported to be due to chemisorption (Yao et al., 2011; Wahab et al., 2011; Jung et al., 2015; Zhang et al., 2016). However, most of these studies did not focus on biochar at different pyrolysis temperatures. It is, therefore, important to clarify the magnitude of the chemical interactions between $\mathrm{PO}_{4}-\mathrm{P}$ and biochar at different pyrolysis temperatures as a function of time and $\mathrm{pH}$ in a chemical system. In the present study, $\mathrm{PO}_{4}-\mathrm{P}$ adsorption dynamics on four biochar types at two pyrolysis temperatures were investigated. The objectives of the study were to (1) determine contact time and $\mathrm{pH}$ effect on $\mathrm{PO}_{4}-\mathrm{P}$ adsorption and (2) to elucidate possible mechanism for $\mathrm{PO}_{4}-\mathrm{P}$ adsorption onto biochar.

\section{Materials and methods}

\subsection{Biochar}

The four biochar types produced at two different pyrolysis temperatures $\left(300^{\circ} \mathrm{C}\right.$ and $\left.650{ }^{\circ} \mathrm{C}\right)$ from cocoa pod husk $(\mathrm{CP})$ (Theobroma cacao), corn cob (CC) (Zea mays), rice husk (RH) (Oryza sativa) and palm kernel shell (PK) (Elaeis guineensis) were obtained from the Soil Research Institute of the Council for Scientific and Industrial Research (CSIR), Ghana. All biochars were finely ground to $<1 \mathrm{~mm}$ using a mortar and pestle and stored in air-tight bags until characterization and kinetics studies. The $\mathrm{CP}, \mathrm{CC}, \mathrm{RH}$ and PK feedstocks pyrolyzed at $300{ }^{\circ} \mathrm{C}$ and $650{ }^{\circ} \mathrm{C}$ are herein after designated as $\mathrm{CP} 300$, CP650, CC300, CC650, RH300, RH650, PK300 and PK650, respectively. Detailed description of the biochar types used for the study are shown in Table 1 . Briefly, the $\mathrm{pH}$, total $\mathrm{P}$, total $\mathrm{C}$, the concentration of the base cations $(\mathrm{Ca}, \mathrm{Mg}, \mathrm{K}$ and $\mathrm{Na}$ ) and heavy metals ( $\mathrm{Fe}$ and $\mathrm{Al}$ ) increased with increasing pyrolysis temperature with the exception of the of total $\mathrm{N}$ and cation exchange capacity (CEC) which decreased otherwise.

\subsection{Fourier transform infrared (FTIR) analysis and Boehm titration}

The functional groups on the biochar types were examined using photoacoustic spectroscopy (PAS)-FTIR. In short, the spectra were recorded using a Nicolet 6700 (Thermo Scientific, USA) spectrometer equipped with a PA-301 photoacoustic 
detector (Gasera Ltd., Finland). For each sample, 128 scans in the mid-infrared region between 4000 and $500 \mathrm{~cm}^{-1}$ at a resolution of $4 \mathrm{~cm}^{-1}$ were recorded and averaged. Boehm titration method was used to determine surface acid functional groups on the biochar types (Boehm, 1994; Usman et al., 2015). Shortly, after adjusting the pH of biochar (1.0 g) and deionized water $\left(40 \mathrm{~cm}^{3}\right)$ suspension to 5.0, it was left undisturbed for 7 days, dried at $60{ }^{\circ} \mathrm{C}$, and homogenized. To each of $10 \mathrm{~mL}$ of $0.05 \mathrm{M} \mathrm{NaOH}, 0.10 \mathrm{~g}$ of the homogenized biochar samples was added. The mixtures, along with a control sample (i.e. solution without biochar), were shaken for $24 \mathrm{~h}$. An aliquot of $5 \mathrm{~mL}$ of the filtrates was then pre-neutralized with $10 \mathrm{~mL}$ of $0.05 \mathrm{M} \mathrm{HCl}$ and titrated to $\mathrm{pH} 7.0$ by adding $0.05 \mathrm{M} \mathrm{NaOH}$ solution at a rate of $0.5 \mathrm{~mL} \mathrm{~min}^{-1}$ controlled by a TIM automatic titration system (Radiometer, France). The calculation for surface acid functional groups was done on the basis that $0.05 \mathrm{M} \mathrm{NaOH}$ neutralizes all acidic groups including carboxyl, lactonic, and phenolic groups (Boehm, 1994; Jiang et al., 2015).

\subsection{Kinetics analysis and $\mathrm{pH}$ effect on $\mathrm{PO}_{4}-\mathrm{P}$ adsorption}

Kinetics study was carried out to determine the equilibrium time of $\mathrm{PO}_{4}-\mathrm{P}$ adsorption onto the biochar types. $\mathrm{PO}_{4}-\mathrm{P}$ solution was prepared by dissolving potassium dihydrogen phosphate $\left(\mathrm{KH}_{2} \mathrm{PO}_{4}\right)$ in $10 \mathrm{mM}$ potassium chloride $(\mathrm{KCl})$. The $\mathrm{PO}_{4}-\mathrm{P}$ kinetics of each biochar were examined by mixing $0.5 \mathrm{~g}$ of biochar with $30 \mathrm{~mL}$ of $100 \mathrm{mg} \mathrm{L} \mathrm{L}^{-1} \mathrm{PO}_{4}-\mathrm{P}$ solution in $50 \mathrm{~mL}$ centrifuge tubes. The tubes were shaken on an end-to-end shaker at $120 \mathrm{rpm}$ for $24 \mathrm{~h}$ at room temperature $\left(22 \pm 0.5^{\circ} \mathrm{C}\right)$. A tube was withdrawn after the shaking was done for $1,3,5,9,15$ and $24 \mathrm{~h}$. The suspension was then centrifuged ( $3500 \mathrm{rpm}, 15 \mathrm{~min}$ ) and the resulting supernatant was filtered through a $0.45 \mu \mathrm{m}$ filter paper. The filtrate was analyzed for $\mathrm{PO}_{4}-\mathrm{P}$ by the colorimetric molybdenum-blue method (John, 1970).

The effect of solution $\mathrm{pH}$ on $\mathrm{PO}_{4}$-P adsorption onto biochars was studied in an initial pH range of 2.5, 3.5, 4.5, 5.5, 6.5, 7.5 and 8.5. The $\mathrm{pH}$ was adjusted using $4 \mathrm{M} \mathrm{HCl}$ or $\mathrm{NaOH}$. The ratio of biochar to the initial solution $\mathrm{PO}_{4}-\mathrm{P}$ concentration was the same as the kinetics experiment. Furthermore, for each $\mathrm{pH}$, a blank $(0.5 \mathrm{~g}$ biochar per $30 \mathrm{~mL}$ deionized water without $\mathrm{PO}_{4}-\mathrm{P}$ solution) was also included. The centrifuge tubes were shaken on an end-to-end shaker at $120 \mathrm{rpm}$ for $24 \mathrm{~h}$ at room temperature $\left(22 \pm 0.5^{\circ} \mathrm{C}\right.$ ). The suspension was then centrifuged $(3500 \mathrm{rpm}, 15 \mathrm{~min}$ ) and the resulting supernatant was filtered through a $0.45 \mu \mathrm{m}$ filter paper. The filtrate was analyzed for $\mathrm{PO}_{4}-\mathrm{P}$ by the colorimetric molybdenum-blue method (John, 1970) and equilibrium (final) $\mathrm{pH}$ was also measured. The initial aqueous $\mathrm{PO}_{4}-\mathrm{P}_{\text {concentration }} C_{i}\left(\mathrm{mg} \mathrm{L}^{-1}\right)$ and the equilibrium $\mathrm{PO}_{4}-\mathrm{P}$ concentration $C_{e}\left(\mathrm{mg} \mathrm{L}^{-1}\right)$ were measured and the $\mathrm{PO}_{4}-\mathrm{P}$ adsorbed $\left(q_{t}\right)$ was computed from the mass balance equation (Eq. (1)):

$$
q_{t}=\frac{\left(C_{i}-C_{e}\right) V}{M}
$$

Here, $V$ is the volume of the aqueous solution (L) and $M$ is the dry weight in grams of biochar (adsorbent).

The kinetics experiments and the effect of equilibrium $\mathrm{pH}$ on $\mathrm{PO}_{4}-\mathrm{P}$ adsorption experiments were repeated three times. The average data and standard errors are reported.

\subsection{Statistical analysis}

The coefficient of determination $\left(R^{2}\right)$, standard error and other statistics, as well as fitting all kinetics data were done using Origin Pro 8.5 and RStudio v.3.4.2. The standard errors of the fitted coefficients were within $95 \%$ confidence intervals. Error bars were used to represent standard errors of triple determinations.

\section{Results and discussion}

\subsection{Biochar FTIR and Boehm titration}

FTIR spectrum of $\mathrm{CC}, \mathrm{PK}, \mathrm{CP}$ and $\mathrm{RH}$ at $300{ }^{\circ} \mathrm{C}$ and $650^{\circ} \mathrm{C}$ revealed the information about adsorption process (Fig. 1). The bands at 1720/1396, 3400 and $2925 \mathrm{~cm}^{-1}$ prove the existence of carboxylic $\mathrm{C}(-\mathrm{COOH})$, phenolic O-H and aliphatic $-\mathrm{CH}_{2}$ stretch, respectively (Chun et al., 2004; Bourke et al., 2007; Brewer et al., 2009). These vibrational bands were relatively intensed at $300{ }^{\circ} \mathrm{C}$-biochar types as compared to their counterparts. The decrease in peaks $3400 \mathrm{~cm}^{-1}, 1396 \mathrm{~cm}^{-1}$ and $1720 \mathrm{~cm}^{-1}$ at $650{ }^{\circ} \mathrm{C}$ suggests the decrease in acid functional groups at high pyrolysis temperature (Brewer et al., 2009). Usman et al. (2015) and Chun et al. (2004) also reported a decrease in -COOH groups (acid functional group) with increasing pyrolysis temperature and even disappearance at high temperature. A well-stretched band centered around $800 \mathrm{~cm}^{-1}$ and $1100 \mathrm{~cm}^{-1}$ correspond to silicates (Bourke et al., 2007). Another noticeable band was seen at $875 \mathrm{~cm}^{-1}$, which is assigned carbonate (Brewer et al., 2009). Results from the Boehm titration were used to further quantify the acid functional groups on the biochar types at the two temperature regimes $\left(300^{\circ} \mathrm{C}\right.$ and $650{ }^{\circ} \mathrm{C}$ ) (Table 1$)$. Obviously, the surface acid functional groups (carboxylic, phenolic and lactonic groups) varied with feedstock and pyrolysis temperature. The dominance of the total surface acid functional groups on the biochar types were in the order of CC $(0.97-2.10 \mathrm{mmol}$ $\left.\mathrm{g}^{-1}\right)>$ CP $\left(0.94-2.12 \mathrm{mmol} \mathrm{g}^{-1}\right)>\mathrm{RH}\left(0.60-2.04 \mathrm{mmol} \mathrm{g}^{-1}\right)>$ PK $\left(0.80-1.82 \mathrm{mmol} \mathrm{g}^{-1}\right)$. Consistent with the results of the FTIR, the content of surface acid functional groups decreased with increasing pyrolysis temperature, indicating the transformation of aliphatic moieties into aromatic moieties (Chun et al., 2004). The results suggested that biochar types charred at $300{ }^{\circ} \mathrm{C}$ have larger amount of acid functional groups compared to when charred at $650{ }^{\circ} \mathrm{C}$. 


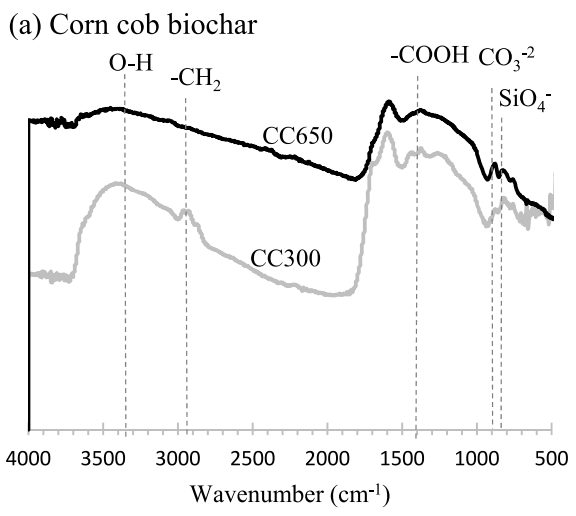

(b) Palm kernel shell biochar $\quad-\mathrm{COOHCO}_{3}^{-2}$

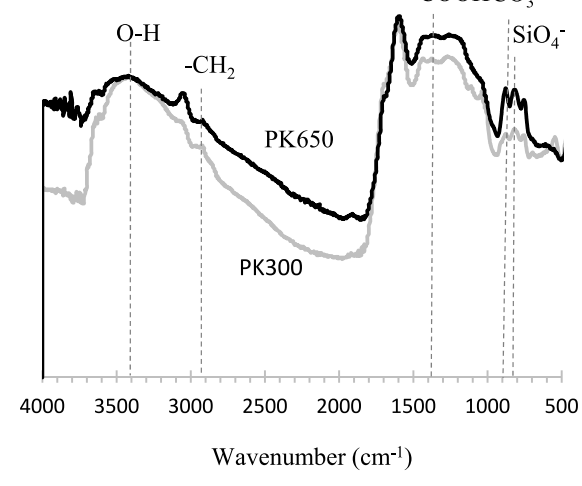

(c) Cocoa pod husk biochar $-\mathrm{COOH} \mathrm{CO}_{3}^{-2}$

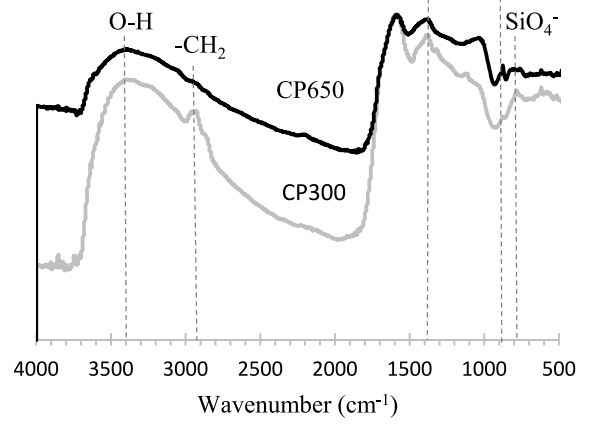

(d) Rice husk biochar

$\mathrm{SiO}_{4}^{-}$

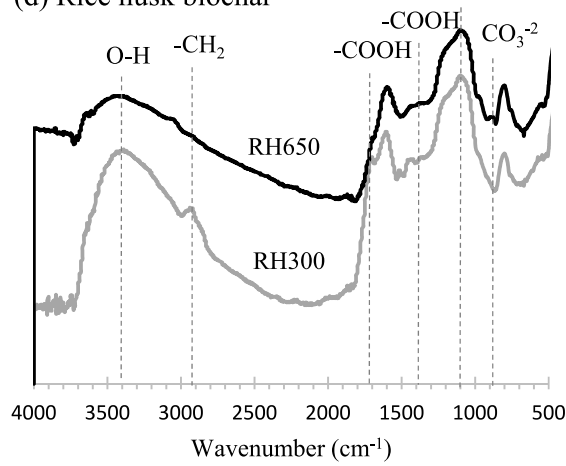

Fig. 1. Photoacoustic spectroscopy-FTIR analysis of (a) corn cob biochar (CC) charred at $300{ }^{\circ} \mathrm{C}$ (CC300) and $650{ }^{\circ} \mathrm{C}$ (CC650), (b) palm kernel shell biochar (PK) charred at $300{ }^{\circ} \mathrm{C}(\mathrm{PK} 300)$ and $650{ }^{\circ} \mathrm{C}$ (PK650), (c) cocoa pod husk biochar (CP) charred at $300{ }^{\circ} \mathrm{C}(\mathrm{CP} 300)$ and $650{ }^{\circ} \mathrm{C}(\mathrm{CP} 650)$, rice husk biochar (RH) charred at $300{ }^{\circ} \mathrm{C}$ (RH300) and $650{ }^{\circ} \mathrm{C}$ (RH650). 
Table 2

Kinetic parameters related to the adsorption of phosphate onto corn cob biochar (CC300 and CC650), palm kernel shell biochar (PK300 and PK650), cocoa pod husk biochar (CP300 and CP650) and rice husk biochar (RH300 and RH650).

\begin{tabular}{|c|c|c|c|c|c|c|c|c|}
\hline \multirow[t]{2}{*}{ Kinetics models } & \multicolumn{8}{|l|}{ Biochar } \\
\hline & CC300 & CC650 & PK300 & PK650 & CP300 & CP650 & RH300 & RH650 \\
\hline Experimental $Q_{e}\left(\mathrm{mg} \mathrm{g}^{-1}\right)$ & 3.6 & 6.5 & 5.0 & 9.4 & 3.0 & 6.0 & 3.9 & 7.6 \\
\hline \multicolumn{9}{|l|}{ Pseudo-first-order } \\
\hline Calculated $q_{\mathrm{e}}\left(\mathrm{mg} \mathrm{g}^{-1}\right)$ & 2.8 & 4.5 & 3.5 & 10.9 & 2.6 & 5.4 & 2.6 & 4.7 \\
\hline$K_{1}\left(\mathrm{~h}^{-1}\right)$ & 0.21 & 0.18 & 0.17 & 0.38 & 0.47 & 0.37 & 0.26 & 0.46 \\
\hline$R^{2}$ & 0.94 & 0.76 & 0.94 & 0.90 & 0.85 & 0.79 & 0.87 & 0.85 \\
\hline \multicolumn{9}{|l|}{ Pseudo-second-order } \\
\hline Calculated $q_{\mathrm{e}}\left(\mathrm{mg} \mathrm{g}^{-1}\right)$ & 4.2 & 7.7 & 5.2 & 10.3 & 2.9 & 6.2 & 4.2 & 8.2 \\
\hline$K_{2}\left(\mathrm{mg} \mathrm{g}^{-1} \mathrm{~h}^{-1}\right)$ & 0.11 & 0.05 & 0.12 & 0.06 & 0.22 & 0.09 & 0.15 & 0.08 \\
\hline$R^{2}$ & 0.99 & 0.98 & 0.99 & 0.99 & 0.99 & 0.99 & 0.99 & 0.99 \\
\hline \multicolumn{9}{|l|}{ Elovich } \\
\hline$\alpha\left(\mathrm{mg} \mathrm{g}^{-1} \mathrm{~h}^{-1}\right)$ & 4.14 & 3.25 & 8.85 & 22.94 & 39.25 & 14.27 & 5.51 & 8.41 \\
\hline$\beta\left(\mathrm{g} \mathrm{mg}^{-1}\right)$ & 1.17 & 0.55 & 1.03 & 0.54 & 2.70 & 0.96 & 1.16 & 0.50 \\
\hline$R^{2}$ & 0.95 & 0.93 & 0.99 & 0.99 & 0.95 & 0.95 & 0.97 & 0.91 \\
\hline \multicolumn{9}{|l|}{ Intraparticle diffusion } \\
\hline$K_{i}\left(\mathrm{mg} \mathrm{g}^{-1} \mathrm{~h}^{0.5}\right)$ & 0.28 & 0.63 & 0.33 & 0.65 & 0.11 & 0.38 & 0.30 & 0.58 \\
\hline$C\left(\mathrm{mg} \mathrm{g}^{-1}\right)$ & 2.00 & 3.90 & 2.50 & 5.30 & 1.91 & 3.05 & 1.68 & 3.00 \\
\hline$R^{2}$ & 0.72 & 0.65 & 0.81 & 0.82 & 0.65 & 0.85 & 0.84 & 0.66 \\
\hline
\end{tabular}

\subsection{Effect of contact time on $\mathrm{PO}_{4}-\mathrm{P}$ adsorption}

Fig. 2 shows contact time effect of $\mathrm{PO}_{4}-\mathrm{P}$ adsorption onto the biochars at the two pyrolysis temperatures, $300{ }^{\circ} \mathrm{C}$ and $650^{\circ} \mathrm{C}$. The results showed that the adsorption of $\mathrm{PO}_{4}-\mathrm{P}$ from solution onto the biochars significantly $(\mathrm{p}<0.05)$ increased in the first few hours and progressively remained stable until approaching an apparent equilibrium varying from 6 to $15 \mathrm{~h}$. The initial rapid phase and the proceeding slow phase of $\mathrm{PO}_{4}-\mathrm{P}$ adsorption is a commonly observed phenomenon (Saeed et al., 2005; Pellera et al., 2012). For a porous adsorbent such as biochar, the initial rapid adsorption phase likely reflected surface adsorption while the subsequent slow phase reflected diffusion of $\mathrm{PO}_{4}-\mathrm{P}$ into the pores. The equilibrium time for maximum $\mathrm{PO}_{4}-\mathrm{P}$ adsorption was faster for the $300{ }^{\circ} \mathrm{C}$-biochar types than the biochar types pyrolyzed at $650{ }^{\circ} \mathrm{C}$. This can be explained by their higher CEC and lower Fe and Al contents (Table 1).

To predict and understand the $\mathrm{PO}_{4}-\mathrm{P}$ kinetics adsorption mechanism, three popular chemical kinetics mathematical models were used, namely pseudo-first-order (PFO), pseudo-second-order (PSO) and Elovich models (Ho, 2006).

$$
\begin{aligned}
\frac{d q_{t}}{d t} & =K_{1}\left(q_{e}-q_{t}\right) \quad \text { Pseudo-first-order } \\
\frac{d q_{t}}{d t} & =K_{2}\left(q_{e}-q_{t}\right)^{2} \quad \text { Pseudo-second-order } \\
\frac{d q_{t}}{d t} & =\alpha \exp \left(-\beta q_{t}\right) \quad \text { Elovich }
\end{aligned}
$$

Here $\mathrm{q}_{\mathrm{t}}\left(\mathrm{mg} \mathrm{g}^{-1}\right)$ and $\mathrm{q}_{\mathrm{e}}\left(\mathrm{mg} \mathrm{g}^{-1}\right)$ are the amount of $\mathrm{P}$ adsorbed at time $\mathrm{t}$ and at equilibrium, respectively, $\mathrm{K}_{1}\left(\mathrm{~h}^{-1}\right)$ and $\mathrm{K}_{2}\left(\mathrm{mg} \mathrm{g}^{-1} \mathrm{~h}^{-1}\right)$ are the PFO and PSO adsorption rate constants, respectively, $\alpha\left(\mathrm{mg} \mathrm{g}^{-1} \mathrm{~h}^{-1}\right)$ is the initial adsorption rate and $\beta\left(\mathrm{g} \mathrm{mg}^{-1}\right)$ is the desorption constant.

PFO and PSO describe the kinetics of the solid-solution system based on physisorption and chemisorption, respectively, with regards to the adsorbent capacity (Ho, 2006). The Elovich model, which was formally used to elucidate the gas adsorption phenomenon, is now widely used to describe the aqueous contaminants sorption by assuming a strong heterogeneity of the sorbent surface (Plazinski et al., 2009). It is an empirical equation which accounts for the contribution of desorption (Yao et al., 2011).

PSO provided a better description of the kinetics of $\mathrm{PO}_{4}-\mathrm{P}$ adsorption than PFO (Fig. 3, Table 2). Aside the high linear dependency of $q_{t}$ on $t\left(R^{2}=0.99\right)$, the calculated $q_{e}$ values of the PSO were closer to the experimental values $\left(Q_{e}\right)$. Thus, the adsorption of $\mathrm{PO}_{4}-\mathrm{P}$ onto the biochars was better characterized by the PSO and thereby occurred through chemisorption (Ho, 2006). The adsorption rate constant, $K_{2}\left(\mathrm{mg} \mathrm{g}^{-1} \mathrm{~h}^{-1}\right)$ ranged from 0.05 to $0.22 \mathrm{mg} \mathrm{g}^{-1} \mathrm{~h}^{-1}$, relatively lower for biochar produced at $650{ }^{\circ} \mathrm{C}$. The higher $K_{2}$ values for the $300{ }^{\circ} \mathrm{C}$-biochars demonstrate an increase rate of $\mathrm{PO}_{4}-\mathrm{P}$ adsorption on these adsorbents than the $650{ }^{\circ} \mathrm{C}$-biochars with time.

The Elovich model also fitted the data well for all the biochar types $\left(R^{2}>0.90\right)$ (Table 2). The adsorption rate, $\alpha$, varied among all the adsorbents (3.25 to $39.25 \mathrm{mg} \mathrm{g}^{-1} \mathrm{~h}^{-1}$ ). Desorption constant, $\beta$ increased in the order of RH650 $<$ PK650 $<$ CC650 < CP650 < PK300 < RH300 < CC300 < CP300. Obviously, the $\beta$ values were relatively higher for the 300 ${ }^{\circ} \mathrm{C}$-biochars than the $650{ }^{\circ} \mathrm{C}$-biochars implying a higher desorption of adsorbed $\mathrm{PO}_{4}-\mathrm{P}$. With regards to the assumption underlying the Elovich model, the active surface sites on the biochars used in the study are heterogeneous and therefore exhibit different activation energy for chemisorption. 


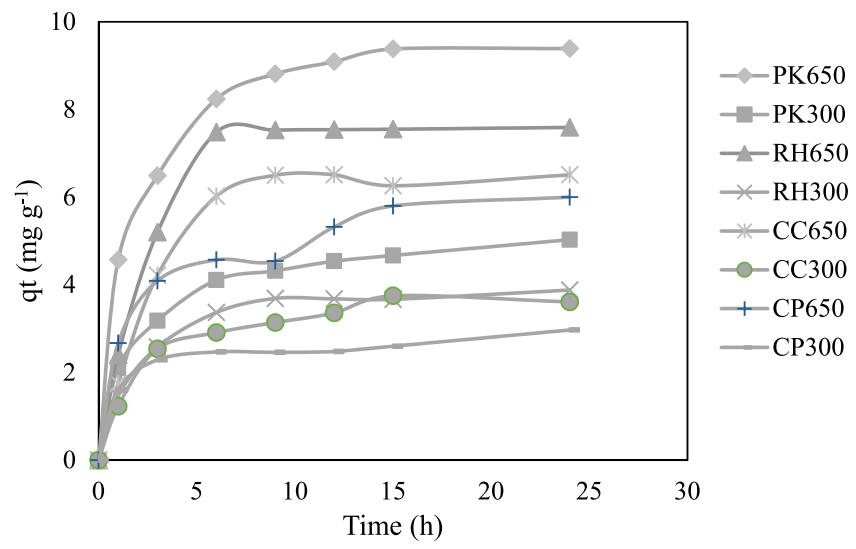

Fig. 2. Effect of contact time on phosphate onto corn cob biochar (CC300 and CC650), palm kernel shell biochar (PK300 and PK650), cocoa pod husk biochar (CP300 and CP650) and rice husk biochar (RH300 and RH650).
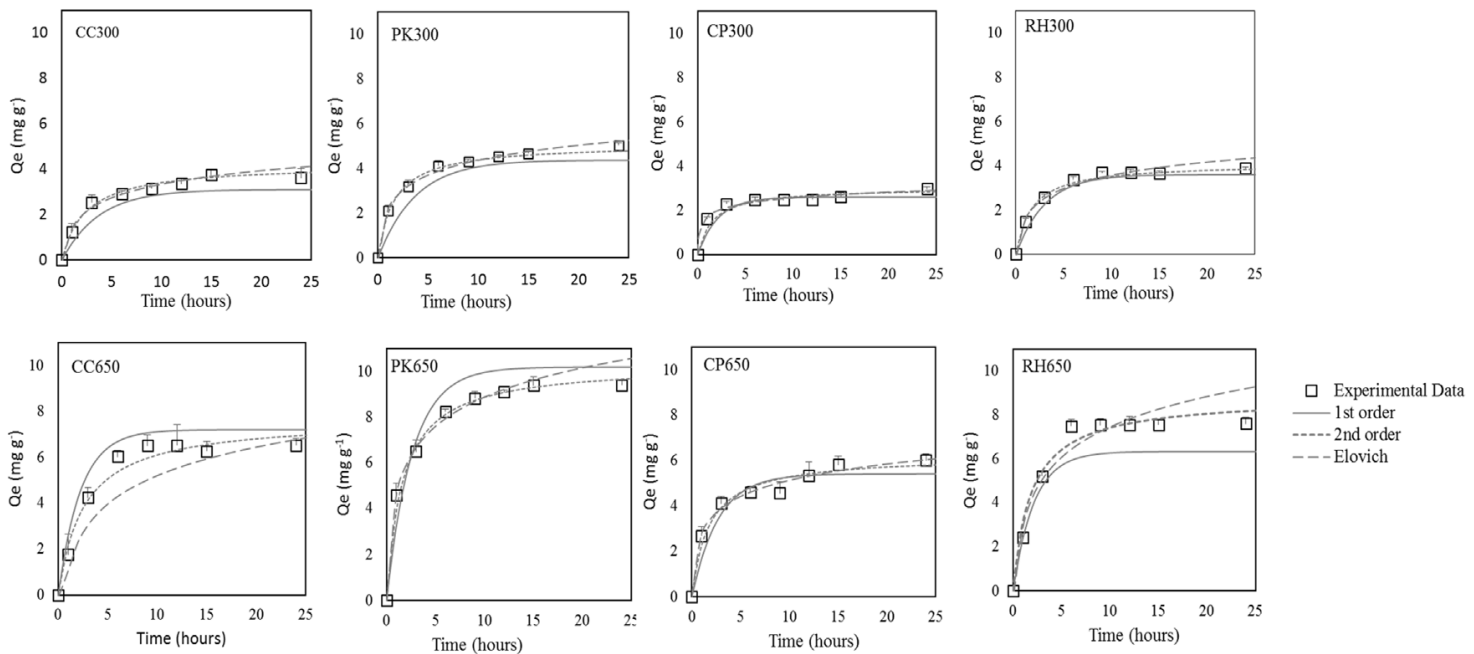

Fig. 3. Kinetics models (Pseudo-first-order, Pseudo-second-order \& Elovich) of phosphate onto corn cob biochar, palm kernel shell biochar, cocoa pod husk biochar and rice husk biochar at $300{ }^{\circ} \mathrm{C}$ and $650{ }^{\circ} \mathrm{C}$.

For a porous adsorbent such as biochar, the diffusion mechanism of $\mathrm{PO}_{4}-\mathrm{P}$ into it is of importance in the adsorption processes. Nonetheless, the chemical kinetics models cannot describe the diffusion mechanism. Intraparticle diffusion model was therefore deployed (Weber and Morris, 1963).

$$
q_{t}=K_{i} t^{1 / 2}+C \text { Intraparticle diffusion }
$$

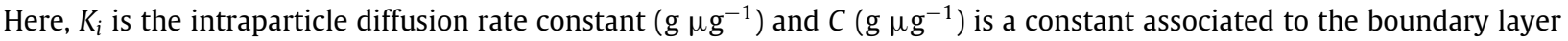
thickness, both can be obtained from the plot of $q_{t}$ versus $t^{0.5}$ (Fig. 4).

$\mathrm{PO}_{4}$-P adsorbed showed a high linear dependency on the square root of time $\left(R^{2}>0.60\right)$, implying that intraparticle diffusion played a role in controlling $\mathrm{PO}_{4}-\mathrm{P}$ adsorption on the biochar types. However, since the $C$ values are greater than zero $(C>0)$ (Table 2), intraparticle diffusion is not the sole rate limiting step. The earlier and later portions of the plot are the film diffusion and intraparticle adsorption stages, respectively. The $K_{i}$ values for the $650{ }^{\circ} \mathrm{C}$-biochars was higher than the $300{ }^{\circ} \mathrm{C}$-biochar types, which could be due to the highly porous nature of biochar produced at high temperatures (Zhang et al., 2015b). The lower values of $C$ observed for $300{ }^{\circ} \mathrm{C}$ - biochars implies that with reference to the rate-limiting step in the overall sorption process in these biochar types, surface film diffusion was less involved.

The validity of the intraparticle model coupled with Elovich and PSO in the present study suggests that $\mathrm{PO}_{4}-\mathrm{P}$ adsorption was initially controlled by chemisorption and subsequently by intraparticle diffusion. These findings are in agreement with the results on P adsorption onto mallee biochar (Zhang et al., 2016). 


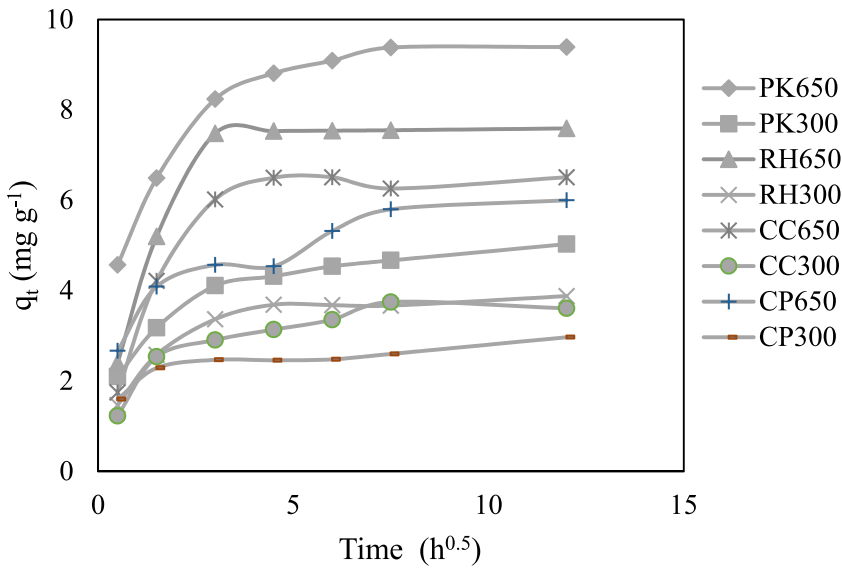

Fig. 4. Intraparticle diffusion modeling for kinetics of phosphate onto corn cob biochar (CC300 and CC650), palm kernel shell biochar (PK300 and PK650), cocoa pod husk biochar (CP300 and CP650) and rice husk biochar (RH300 and RH650).
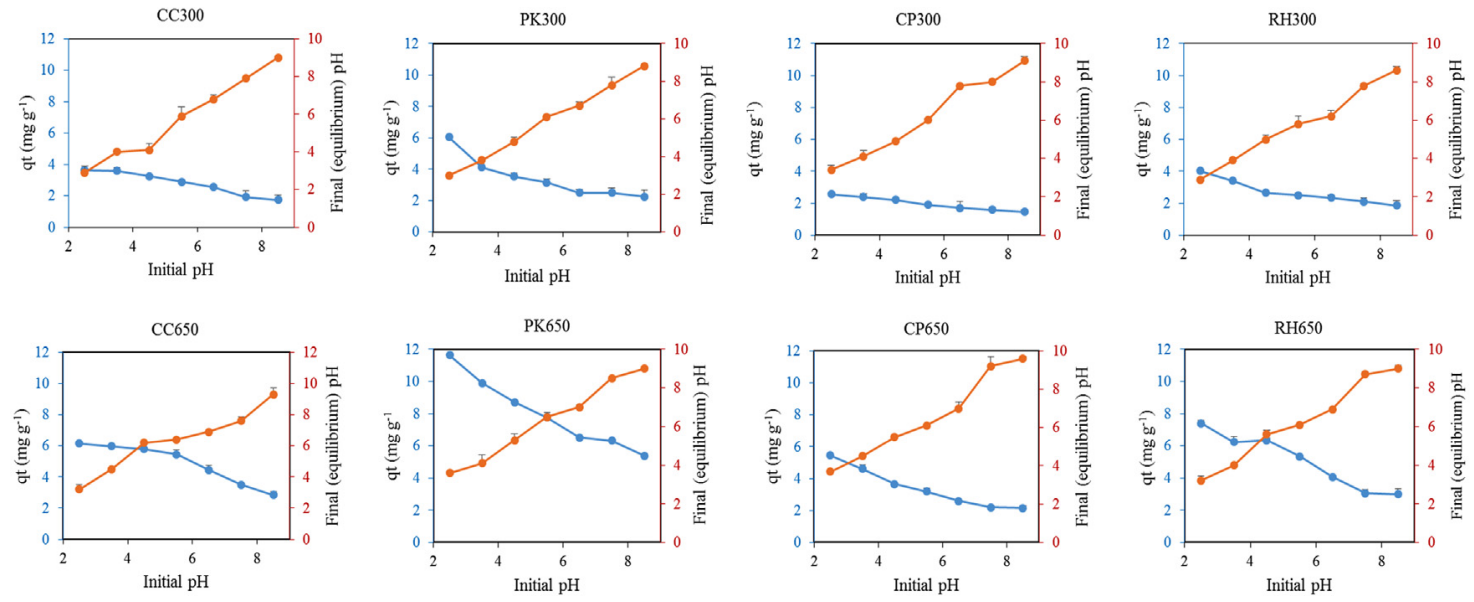

Fig. 5. Effect of pH on the adsorption of phosphate onto corn cob biochar (CC300 and CC650), palm kernel shell biochar (PK300 and PK650), cocoa pod husk biochar (CP300 and CP650) and rice husk biochar (RH300 and RH650). The red and blue colored lines show final pH (equilibrium pH) and amount of phosphate adsorbed (qt), respectively . (For interpretation of the references to color in this figure legend, the reader is referred to the web version of this article.)

\subsection{Effect of $\mathrm{pH}$ on $\mathrm{PO}_{4}-\mathrm{P}$ adsorption}

The amount of the $\mathrm{PO}_{4}-\mathrm{P}$ adsorbed onto the biochars was highly related to $\mathrm{pH}$ (Fig. 5). This implies that pH played a major role in the entire adsorption process, particularly on the speciation of $\mathrm{PO}_{4}-\mathrm{P}$ and the surface charge of the biochar and therefore its adsorption capacity. The amount of $\mathrm{PO}_{4}-\mathrm{P}$ adsorbed was inversely related to the equilibrium $\mathrm{pH}(2.8$ to 9.6) for the biochar types (Fig. 5). Biochar mostly has low point of zero charge (PZC) (Mukherjee et al., 2011) and therefore at $\mathrm{pH}>4.5$ negative surface charges will be created resulting in low $\mathrm{PO}_{4}$-P sorption (Xie et al., 2014). The PAS-FTIR analysis indicated ample amounts of oxygen-containing functional groups among which is carboxylate $(-\mathrm{COOH})$ that contributes considerably to the negative surface charge of the biochar types (Fig. 1). The surface negative potential of biochar decreases with increasing equilibrium $\mathrm{pH}$ ( $\mathrm{Li}$ et al., 2017). Thus, the low affinity of $\mathrm{PO}_{4}-\mathrm{P}$ by the biochars at high solution $\mathrm{pH}$ could be a result of the increased electrostatic anion repulsion between the negatively charged biochar surfaces and the negatively charged $\mathrm{PO}_{4}-\mathrm{P}$ ions, and also because of increased competitive effect of $\mathrm{OH}^{-}$ion.

The equilibrium $\mathrm{pH}$ for maximum $\mathrm{PO}_{4}$-P adsorption onto the biochar types was between 2.6 and 4.8. This was in line with equilibrium pH i.e. 3.0 to 6.5 reported for maximum $\mathrm{PO}_{4}$-P sorption by potato, canola and walnut shell biochar (Feizi and Jalali, 2014). At the observed equilibrium $\mathrm{pH}$ (2.6 to 4.8) of the present study, Fe and Al would be active in solution. However, $\mathrm{Ca}$ and $\mathrm{Mg}$ would be precipitating or polymerizing out of solution. The presence of $\mathrm{Fe}$ and $\mathrm{Al}$, may in part explain $\mathrm{PO}_{4}$-P adsorption on the biochar types. This collaborated with the results of Shepherd et al. (2017), mapping the 
mechanism of $\mathrm{P}$ capture in biochar and also Sibrell et al. (2009), examining $\mathrm{PO}_{4}-\mathrm{P}$ sorption in ochres biochar with differing chemical compositions, that $\mathrm{PO}_{4}-\mathrm{P}$ removal from solution was controlled by $\mathrm{Fe}$ and Al. Similarly, $\mathrm{PO}_{4}-\mathrm{P}$ adsorption on $\mathrm{Al}$ and Fe (hydr)oxide-biochar has been reported (Manning and Goldberg, 1996). The PK650 and RH650 biochar types with relatively high $\mathrm{Al}$ and $\mathrm{Fe}$ concentration had high sorption capacities. The acid functional groups (e.g. - $\mathrm{COOH}$ and $-\mathrm{OH}$ ) are retained at $300{ }^{\circ} \mathrm{C}$ but tended to decrease at $650{ }^{\circ} \mathrm{C}$ (Table 1 \& Fig. 1), culminating in less negative charges and increased PZC at high temperatures (Li et al., 2017). As a consequence, low pyrolysis biochars had a higher CEC relative to high pyrolysis biochars. With higher CEC, it is a matter of course that these biochar types would have the highest repulsion for the $\mathrm{PO}_{4}-\mathrm{P}$ anions which would translate into the least adsorption. The variation in the sorption capacity of the biochar types under the studied $\mathrm{pH}$ range suggests differences in surface functional properties of these biochar types as influenced by pyrolysis temperature and feedstock.

\subsection{Changes in $\mathrm{pH}$ and mechanism of $\mathrm{PO}_{4}-\mathrm{P}$ adsorption}

To fully comprehend the mechanisms of $\mathrm{PO}_{4}-\mathrm{P}$ adsorption onto the biochar types, the $\Delta \mathrm{pH}$ values (difference between equilibrium $\mathrm{pH}$ of biochar sample with $\mathrm{PO}_{4}-\mathrm{P}$ solution and equilibrium $\mathrm{pH}$ of blank) were calculated (Table 3). In accordance with the $\Delta \mathrm{pH}$ values, there was no change in $\mathrm{pH}$ with decreasing $\mathrm{PO}_{4}-\mathrm{P}$ adsorption for PK650, RH300, RH650, CP300, CC300 and CC650 since the $\Delta \mathrm{pH}$ were below $0.5 \mathrm{pH}$ units (Nartey et al., 2000). However, CP650 and PK300 showed respective increase and decrease in $\mathrm{pH}$ which were more than $\mathrm{pH} 0.5$ units. The 0.5 units increase in the $\Delta \mathrm{pH}$ of $\mathrm{CP} 650$ coincided with the maximum $\mathrm{PO}_{4}-\mathrm{P}$ sorption capacity (Table 3), indicating the release of hydroxyl ions $\left(\mathrm{OH}^{-}\right)$during the adsorption process. Similarly, the maximum $\mathrm{PO}_{4}-\mathrm{P}$ adsorption of PK300 coincided with a 0.7 unit decrease in pH (Table 3 ), implying the release of protons $\left(\mathrm{H}^{+}\right.$or $\left.\mathrm{H}_{3} \mathrm{O}^{+}\right)$during the adsorption process.

From the kinetics adsorption study, $\mathrm{PO}_{4}-\mathrm{P}$ adsorption onto the biochars occurred predominantly through chemisorption (Table 2). The maximum $\mathrm{PO}_{4}-\mathrm{P}$ sorption for $\mathrm{CP} 300$, RH650 and CC650 occurred at equilibrium pH from 3.2 to 3.4. Within this equilibrium $\mathrm{pH}$ range (3.2 to 3.4), $\mathrm{Fe}$ and $\mathrm{Al}$ from the ash in the biochar will exists as free $\mathrm{Fe}^{3+}$ and $\mathrm{Al}^{3+}$ ions (Marion et al., 1976). At this equilibrium pH range, 95\% of $\mathrm{PO}_{4}-\mathrm{P}$ exists as $\mathrm{H}_{2} \mathrm{PO}_{4}^{-}$and only $5 \%$ as $\mathrm{H}_{3} \mathrm{PO}_{4}$ since pK1 of $\mathrm{PO}_{4}-\mathrm{P}$ is 2.15 (Lindsay, 1979). Surface precipitation of adsorbed $\mathrm{PO}_{4}-\mathrm{P}$ with $\mathrm{Fe}$ and $\mathrm{Al}$ on $\mathrm{CP} 300$, RH650 and CC650 will thus occur (Eqs. (2) and (3)).

$$
\begin{aligned}
& \mathrm{Fe}^{3+}+3 \mathrm{H}_{2} \mathrm{PO}_{4}^{-} \rightarrow \mathrm{Fe}\left(\mathrm{H}_{2} \mathrm{PO}_{4}\right)_{3} \\
& \mathrm{Al}^{3+}+3 \mathrm{H}_{2} \mathrm{PO}_{4}^{-} \rightarrow \mathrm{Al}\left(\mathrm{H}_{2} \mathrm{PO}_{4}\right)_{3}
\end{aligned}
$$

Phenol group $(-\mathrm{OH})$ was identified on $\mathrm{CP} 300$, $\mathrm{RH} 650$ and $\mathrm{CC} 650$ and can remove $\mathrm{PO}_{4}-\mathrm{P}$ through ligand exchange. Maximum adsorption for CP300, RH650 and CC650 were observed between equilibrium pH 3.2 and 3.4. These pHs are 5.6 to $5.8 \mathrm{pH}$ units below the $\mathrm{pKa}$ of $-\mathrm{OH}(\mathrm{pKa}=9.0$ ) (Evangelou, 1998). Thus, the $-\mathrm{OH}$ functional groups would be protonated. At these equilibrium pHs, the dominant $\mathrm{PO}_{4}-\mathrm{P}$ species in solution is $\mathrm{H}_{2} \mathrm{PO}_{4}{ }^{-}$. $\mathrm{PO}_{4}-\mathrm{P}^{-}$removal from the solution by the protonated phenol may occur via ligand exchange (Eq. (4)) and electrostatic attraction (Eq. (5)):

$$
\begin{aligned}
& \mathrm{R}-\mathrm{OH}_{2}^{+}+\mathrm{H}_{2} \mathrm{PO}_{4}^{-} \rightarrow \mathrm{RH}_{2} \mathrm{PO}_{4}+\mathrm{H}_{2} \mathrm{O} \\
& \mathrm{R}-\mathrm{OH}_{2}^{+}+\mathrm{H}_{2} \mathrm{PO}_{4}^{-} \rightarrow \mathrm{R}-\mathrm{OH}_{2} \mathrm{H}_{2} \mathrm{PO}_{4}
\end{aligned}
$$

Because there were no changes in solution pH after adsorption, Eqs. (4) and (5) are also plausible. In Eq. (3), the $\mathrm{PO}_{4}-\mathrm{P}$ is retained and could be exchanged by other anions (e.g. $\mathrm{Cl}_{-}, \mathrm{NO}_{3}{ }^{-}$) back into solution. In Eq. (4), however, structural $-\mathrm{OH}$ is replaced and the $\mathrm{PO}_{4}-\mathrm{P}$ is locked up. This mechanism may be ideal for water cleansing.

Carboxylic (-COOH), a functional group with pKa value of 4.8 (Sparks 1995) was found on RH300 and CC300. The equilibrium pHs for maximum $\mathrm{PO}_{4}$-P adsorption were 2.6 and 2.7 for $\mathrm{RH} 300$ and $\mathrm{CC} 300$, respectively. The equilibrium pHs (2.6 and 2.7) were more than $2 \mathrm{pH}$ units below the $\mathrm{pKa}$ of $-\mathrm{COOH}$ and therefore it will be protonated. The removal of $\mathrm{PO}_{4}-\mathrm{P}$ by the protonated $-\mathrm{COOH}$ can occur via electrostatic attraction (Eq. (6)). Again, with no change in equilibrium $\mathrm{pH}$ as a result of adsorption, Eq. (6) is plausible. $\mathrm{PO}_{4}-\mathrm{P}$ adsorbed by $\mathrm{RH} 300$ and CC300 is weakly held (electrostatic attraction) and can, therefore, easily be exchanged by other anions in the solution.

$$
\mathrm{R}-\mathrm{COOH}_{2}^{+}+\mathrm{H}_{2} \mathrm{PO}_{4}^{-} \rightarrow \mathrm{R}-\mathrm{COOH}_{2} \mathrm{H}_{2} \mathrm{PO}_{4}
$$

The maximum $\mathrm{PO}_{4}-\mathrm{P}$ adsorption capacity of $\mathrm{PK} 650$ occurred at equilibrium $\mathrm{pH}$ of 3.6. At this $\mathrm{pH}$, and with the presence of $\mathrm{Fe}^{3+}$ and $\mathrm{Al}^{3+}$, there could be species of $\mathrm{FeOH}_{2}{ }^{+}$and $\mathrm{AlOH}_{2}{ }^{+}$in the solution (Marion et al., 1976). There was also no change in equilibrium pH after adsorption. Thus, in addition to surface precipitation (Eqs. (2) and (3)), PK650 can also adsorb $\mathrm{PO}_{4}-\mathrm{P}$ by ligand exchange (Eqs. (7) and (8)).

$$
\begin{aligned}
& \mathrm{Fe}-\mathrm{OH}_{2}^{+}+\mathrm{H}_{2} \mathrm{PO}_{4}^{-} \rightarrow \mathrm{Fe}-\mathrm{O}-\mathrm{H}_{2} \mathrm{PO}_{3}+\mathrm{H}_{2} \mathrm{O} \\
& \mathrm{Al}-\mathrm{OH}_{2}^{+}+\mathrm{H}_{2} \mathrm{PO}_{4}^{-} \rightarrow \mathrm{Al}-\mathrm{O}-\mathrm{H}_{2} \mathrm{PO}_{3}+\mathrm{H}_{2} \mathrm{O}
\end{aligned}
$$

The equilibrium $\mathrm{pH}$ (4.1) at which maximum $\mathrm{PO}_{4}-\mathrm{P}$ adsorption occurred on PK300 coincided with a 0.7 unit decrease in equilibrium $\mathrm{pH}$, implying a release of proton after $\mathrm{PO}_{4}-\mathrm{P}$ adsorption. At the equilibrium $\mathrm{pH}$ of $4.1, \mathrm{Fe}^{3+}, \mathrm{Al}^{3+}, \mathrm{FeOH}_{2}{ }^{+}$, $\mathrm{AlOH}_{2}{ }^{+}, \mathrm{FeOH}^{2+}$ and $\mathrm{AlOH}^{2+}$ all exist in solution monomeric forms of Fe and Al (Marion et al., 1976). At this equilibrium 
Table 3

Changes in $\mathrm{pH}$ and amount of phosphate adsorbed by the biochar types.

\begin{tabular}{|c|c|c|c|c|c|c|c|c|c|c|c|c|c|c|c|}
\hline \multicolumn{4}{|c|}{ Corn cob biochar } & \multicolumn{4}{|c|}{ Palm kernel shell biochar } & \multicolumn{4}{|c|}{ Cocoa pod husk biochar } & \multicolumn{4}{|c|}{ Rice husk biochar } \\
\hline \multicolumn{2}{|c|}{ CC300 } & \multicolumn{2}{|c|}{ CC650 } & \multicolumn{2}{|c|}{ PK300 } & \multicolumn{2}{|c|}{ PK650 } & \multicolumn{2}{|c|}{ СР300 } & \multicolumn{2}{|c|}{ CP650 } & \multicolumn{2}{|c|}{ RH300 } & \multicolumn{2}{|c|}{ RH650 } \\
\hline$\Delta \mathrm{pH}^{\mathrm{a}}$ & $\begin{array}{l}\mathrm{PO}_{4}-\mathrm{P} \\
\text { adsorbed } \\
\left(\mathrm{mg} \mathrm{g}^{-1}\right)\end{array}$ & $\overline{\Delta \mathrm{pH}}$ & $\begin{array}{l}\mathrm{PO}_{4}-\mathrm{P} \\
\text { adsorbed } \\
\left(\mathrm{mg} \mathrm{g}^{-1}\right)\end{array}$ & $\Delta \mathrm{pH}$ & $\begin{array}{l}\mathrm{PO}_{4}-\mathrm{P} \\
\text { adsorbed } \\
\left(\mathrm{mg} \mathrm{g}^{-1}\right)\end{array}$ & $\overline{\Delta \mathrm{pH}}$ & $\begin{array}{l}\mathrm{PO}_{4}-\mathrm{P} \\
\text { adsorbed } \\
\left(\mathrm{mg} \mathrm{g}^{-1}\right)\end{array}$ & $\overline{\Delta \mathrm{pH}}$ & $\begin{array}{l}\mathrm{PO}_{4}-\mathrm{P} \\
\text { adsorbed } \\
\left(\mathrm{mg} \mathrm{g}^{-1}\right)\end{array}$ & $\overline{\Delta \mathrm{pH}}$ & $\begin{array}{l}\mathrm{PO}_{4}-\mathrm{P} \\
\text { adsorbed } \\
\left(\mathrm{mg} \mathrm{g}^{-1}\right)\end{array}$ & $\overline{\Delta \mathrm{pH}}$ & $\begin{array}{l}\mathrm{PO}_{4}-\mathrm{P} \\
\text { adsorbed } \\
\left(\mathrm{mg} \mathrm{g}^{-1}\right)\end{array}$ & $\overline{\Delta \mathrm{pH}}$ & $\begin{array}{l}\mathrm{PO}_{4}-\mathrm{P} \\
\text { adsorbed } \\
\left(\mathrm{mg} \mathrm{g}^{-1}\right)\end{array}$ \\
\hline-0.2 & 3.64 & 0.0 & 5.99 & 0.1 & 4.11 & 0.0 & 11.63 & 0.3 & 2.57 & 0.3 & 4.60 & -0.3 & 4.02 & -0.2 & 7.40 \\
\hline 0.3 & 3.59 & 0.2 & 6.25 & -0.7 & 6.05 & -0.1 & 9.90 & 0.2 & 2.39 & 0.5 & 5.45 & -0.2 & 3.40 & -0.2 & 6.25 \\
\hline-0.2 & 3.25 & -0.2 & 5.79 & -0.1 & 3.54 & -0.1 & 8.72 & -0.1 & 2.22 & 0.1 & 3.65 & 0.2 & 2.65 & 0.2 & 6.35 \\
\hline-0.3 & 2.90 & -0.3 & 5.46 & -0.2 & 3.15 & -0.1 & 7.77 & -0.3 & 1.89 & -0.1 & 3.20 & -0.1 & 2.50 & -0.4 & 5.35 \\
\hline-0.1 & 2.55 & -0.1 & 4.45 & -0.2 & 2.51 & -0.1 & 6.53 & 0.4 & 1.70 & 0.0 & 2.60 & 0.3 & 2.35 & 0.2 & 4.06 \\
\hline 0.1 & 1.92 & -0.3 & 3.50 & 0.1 & 2.50 & 0.1 & 6.32 & -0.3 & 1.60 & -0.3 & 2.20 & -0.1 & 2.10 & 0.3 & 3.05 \\
\hline 0.3 & 1.75 & 0.4 & 2.85 & 0.0 & 2.25 & -0.2 & 5.38 & -0.1 & 1.45 & 0.2 & 2.15 & 0.4 & 1.85 & 0.2 & 3.00 \\
\hline
\end{tabular}

${ }^{\mathrm{a}}$ The difference between equilibrium $\mathrm{pH}$ of biochar sample with $\mathrm{PO}_{4}-\mathrm{P}$ solution and equilibrium $\mathrm{pH}$ of blank without $\mathrm{PO}_{4}-\mathrm{P}$ solution. 
pH (4.1), 95\% of $\mathrm{PO}_{4}-\mathrm{P}$ exist as $\mathrm{H}_{2} \mathrm{PO}_{4}{ }^{-}$and $5 \%$ as $\mathrm{H}_{3} \mathrm{PO}_{4}$ (Lindsay, 1979). $\mathrm{PO}_{4}-\mathrm{P}$ adsorption by $\mathrm{PK} 300$ can, therefore, occur by precipitation and ligand exchange with a concomitant release of protons (Eqs. (9)-(14)).

$$
\begin{aligned}
& \mathrm{Fe}^{3+}+\mathrm{H}_{2} \mathrm{PO}_{4}^{-}+2 \mathrm{H}_{2} \mathrm{O} \rightarrow \mathrm{Fe}(\mathrm{OH})_{2} \mathrm{H}_{2} \mathrm{PO}_{4}+2 \mathrm{H}^{+} \\
& \mathrm{Al}^{3+}+\mathrm{H}_{2} \mathrm{PO}_{4}^{-}+2 \mathrm{H}_{2} \mathrm{O} \rightarrow \mathrm{Al}(\mathrm{OH})_{2} \mathrm{H}_{2} \mathrm{PO}_{4}+2 \mathrm{H}^{+} \\
& \mathrm{Fe}-\mathrm{OH}^{2+}+\mathrm{H}_{2} \mathrm{PO}_{4}^{-} \rightarrow \mathrm{FeH} \mathrm{PO}_{4}+\mathrm{H}^{+} \\
& \mathrm{Al}-\mathrm{OH}^{2+}+\mathrm{H}_{2} \mathrm{PO}_{4}^{-} \rightarrow \mathrm{Al}-\mathrm{O}-\mathrm{H}_{2} \mathrm{PO}_{3}+\mathrm{H}^{+} \\
& \mathrm{Fe}-\mathrm{OH}_{2}^{+}+\mathrm{H}_{3} \mathrm{PO}_{4} \rightarrow \mathrm{Fe}-\mathrm{O}-\mathrm{H}_{2} \mathrm{PO}_{3}+\mathrm{H}_{3} \mathrm{O}^{+} \\
& \mathrm{Al}-\mathrm{OH}_{2}^{+}+\mathrm{H}_{3} \mathrm{PO}_{4} \rightarrow \mathrm{Al}-\mathrm{O}-\mathrm{H}_{2} \mathrm{PO}_{3}+\mathrm{H}_{3} \mathrm{O}^{+}
\end{aligned}
$$

However, as the decrease in pH was only $0.7 \mathrm{pH}$ units, it is unlikely that Eqs. (9) and (10) occurred since these equations depict the release of 2 moles of $\mathrm{H}^{+}$that would have accounted for a greater decrease in $\mathrm{pH}$. The more plausible reactions are thus Eqs. (11)-(14).

The maximum $\mathrm{PO}_{4}-\mathrm{P}$ adsorption onto $\mathrm{CP} 650$ occurred at an equilibrium $\mathrm{pH}$ of 3.2. At this $\mathrm{pH}$ the $-\mathrm{COOH}$ will exist mainly in its neutral form. $\mathrm{PO}_{4}-\mathrm{P}$ adsorption by $-\mathrm{COOH}$ can occur via ligand exchange with a concomitant release of $\mathrm{OH}^{-}$ ions (Eq. (15)).

$$
\mathrm{RCOOH}+\mathrm{H}_{2} \mathrm{PO}_{4}^{-} \rightarrow \mathrm{RCOH}_{2} \mathrm{PO}_{4}+\mathrm{OH}^{-}
$$

In summary, the mechanisms of $\mathrm{PO}_{4}-\mathrm{P}$ adsorption onto the biochar types were diversiform, mainly including electrostatic attraction, surface precipitation and ligand exchange; which depended largely on the feedstock and the pyrolysis temperature.

\section{Conclusion}

The study indicated that the biochar types have affinity for $\mathrm{PO}_{4}-\mathrm{P}$ adsorption. $\mathrm{PO}_{4}-\mathrm{P}$ adsorption was faster on the low pyrolysis biochar types $\left(300{ }^{\circ} \mathrm{C}\right)$ as compared to their counterparts $\left(650{ }^{\circ} \mathrm{C}\right)$. Increasing pyrolysis temperature proportionally increased the $\mathrm{PO}_{4}-\mathrm{P}$ adsorption. Maximum $\mathrm{PO}_{4}-\mathrm{P}$ adsorption on the biochar types occurred at low pHs (2.6-4.8). The adsorption of $\mathrm{PO}_{4}-\mathrm{P}$ onto the heterogeneous surface of the biochar types was predominantly controlled by intraparticle diffusion and chemisorption (electrostatic attraction, surface precipitation and ligand exchange). The use of RH300 and CC300 present an interesting option for waste recycling as a slow $\mathrm{PO}_{4}$-P releasing fertilizer. PK, CP, CC650 and RH650 can also serve as a strong $\mathrm{PO}_{4}-\mathrm{P}$ adsorbent in tertiary wastewater treatment since the $\mathrm{PO}_{4}-\mathrm{P}$ adsorbed (surface precipitation and ligand exchange) cannot easily be desorbed.

\section{Declaration of competing interest}

The authors declare that they have no known competing financial interests or personal relationships that could have appeared to influence the work reported in this paper.

\section{CRediT authorship contribution statement}

Joseph Osafo Eduah: Conceptualization, Methodology, Investigation, Visualization, Formal analysis, Writing - original draft. Eric Kwesi Nartey: Supervision, Methodology, Writing - review \& editing. Mark Kofi Abekoe: Supervision, Methodology, Writing - review \& editing. Stephan Weck Henriksen: Investigation, Resources, Formal analysis. Mathias Neumann Andersen: Writing - review \& editing, Funding acquisition.

\section{Acknowledgments}

The study was supported by Danida (Ministry of Foreign Affairs of Denmark) under the project "Green Cohesive Agricultural Resource Management, WEBSOC", DFC project no: 13-01AU.

The authors would like to thank Professor Ole K. Borggaard and the late Professor Henrik Breuning-Madsen for their supervision during the research stay of Joseph Osafo Eduah at University of Copenhagen, Denmark. We are also grateful to Dr. Marie Louise Bornø (University of Copenhagen) for her assistance in biochar analysis.

\section{References}

Almeelbi, T., Bezbaruah, A., 2012. Aqueous phosphate removal using nanoscale zero-valent iron. J. Nanopart. Res. 14, 1-14.

Biswas, B.K., Inoue, K., Ghimire, K.N., Harada, H., Ohto, K., Kawakita, H., 2008. Removal and recovery of phosphorus from water by means of adsorption onto orange waste gel loaded with zirconium. Bioresour. Technol. 99, 8685-8690.

Boehm, H.P., 1994. Some aspects of the surface chemistry of carbon blacks and other carbons. Carbon 32, 759-769.

Bourke, J., Manley-Harris, M., Fushimi, C., Dowaki, K., Nunoura, T., Antal, M.J., 2007. Do all carbonized charcoals have the same chemical structure? A model of the chemical structure of carbonized charcoal. Ind. Eng. Chem. Res. 46, 5954-5967. 
Brewer, C.E., Schmidt-Rohr, K., Satrio, J.A., Brown, R.C., 2009. Characterization of biochar from fast pyrolysis and gasification systems. Environ. Progress. Sustain. Energy 28, 386-396.

Chun, Y., Sheng, G.Y., Chiou, C.T., Xing, B.S., 2004. Compositions and sorptive properties of crop residue-derived chars. Environ. Sci. Technol. 38, 4649-4655.

Demirbas, A., 2008. Production and characterization of bio-chars from biomass via pyrolysis. Energy Sources A $28,413-422$.

Dodds, W.K., Bouska, W.W., Eitzmann, J.L., Pilger, T.J., Pitts, K.L., Riley, A.J., Schloesser, J.T., Thornbrugh, D.J., 2008. Eutrophication of US freshwaters: Analysis of potential economic damages. Environ. Sci. Technol. 43, 12-19.

Evangelou, V.P., 1998. Environmental Soil and Water Chemistry: Principles and Applications. John Wiley and Sons. Inc., Canada.

Feizi, M., Jalali, M., 2014. Sorption of aquatic phosphorus onto native and chemically-modified plant residues: modeling the isotherm and kinetics of sorption process. Desalin. Water Treat. 45, 121-133.

Ho, Y.S., 2006. Review of second-order models for adsorption systems. J. Hazard. Mater. 136, 681-689.

Jiang, J., Yuan, M., Renkou, X., Bish, D.L., 2015. Mobilization of phosphate in variable-charge soils amended with biochars derived from crop straws. Soil Tillage Res. 146, 139-147.

John, M.K., 1970. Colorimetric determination of phosphorus in soil and plant materials with ascorbic acid. Soil Sci. 109 (4), 214-220.

Jung, K.W., Ok, Y.S., Hwang, M.J., Ahn, K.H., 2015. Kinetic study on phosphate removal from aqueous solution by biochar derived from peanut shell as renewable adsorptive media. Int. J. Environ. Sci. Technol. 12, 3363-3372.

Kasozi, G.N., Zimmerman, A.R., Nkedi-Kizza, P., Gao, B., 2010. Catechol and humic acid sorption onto a range of laboratory-produced black carbons (Biochars). Environ. Sci. Technol. 44, 6189-6195.

Lehmann, J., 2007. Bio-energy in the Black. Front. Ecol. Environ. 5, 381-387.

Li, H., Dong, X., da Silva, E.B., de Oliveira, L.M., Chen, Y., Ma, L.Q., 2017. Mechanisms of metal sorption by biochars: Biochar characteristics and modifications. Chemosphere 178, 466-478.

Lindsay, W.L., 1979. Chemical Equilibria in Soils. John Wiley \& Sons, New York.

Manning, B.A., Goldberg, S., 1996. Modeling competitive adsorption of arsenate with phosphate and molybdate on oxide minerals. Soil Sci. Am. J. 60 121-131.

Marion, G.M., Hendricks, D.M., Dutt, G.R., Filler, W.H., 1976. Aluminum and silica solution in soils. Soil Sci. 127, 76-85.

Mukherjee, A., Zimmerman, A.R., Harris, W., 2011. Surface chemistry variations among a series of laboratory-produced biochars. Geoderma 163 , 247-255.

Nartey, E., Matsue, N., Henmi, T., 2000. Adsorptive mechanism of orthosilic acid on nano ball allophane. Clay Sci. 11, 125-136.

Pellera, F.M., Giannis, A., Kalderis, D., Anastasiadou, K., Stegmann, R., Wang, J.Y., Gidarakos, E., 2012. Adsorption of Cu (II) ions from aqueous solutions on biochars prepared from agricultural byproducts. J. Environ. Manag. 96, 35-42.

Plazinski, W., Rudzinski, W., Palzinska, A., 2009. Theoretical models of sorption kinetics including a reaction mechanism: a review. Adv. Colloid Interface Sci. 152, 2-13.

Saeed, A., Akhter, M.W., Iqbal, M., 2005. Removal and recovery of heavy metals from aqueous solution using papaya wood as a new biosorbent. Sep. Purif. Technol. 45, 25-31.

Shepherd, J.G., Joseph, S., Sohi, S.P., Heal, K.V., 2017. Biochar and enhanced phosphate capture: Mapping mechanisms to functional properties. Chemosphere 179, 57-74.

Sibrell, P.L., Montgomery, G.A., Ritenour, K.L., Tucker, T.W., 2009. Removal of phosphorus from agricultural wastewaters using adsorption media prepared from acid mine drainage sludge. Water Res. 43, 2240-2250.

1995. USEPA Ecological Restoration: A Tool to Manage Stream Quality. Report EPA 841-F-95-007, US EPA, Washington, DC, USA.

Usman, A.R.A., Abduljabbar, A., Vithanage, M., Ok, Y.S., Ahmad, M., Ahmad, M., Elfaki, J., Abdulazeem, S., Al-Wabel, M.I., 2015. Biochar production from date palm waste: Charring temperature induced changes in composition and surface chemistry. J. Anal. Appl. Pyrolysis 115, 392-400.

Wahab, M.A., Hassine, R.B., Jellali, S., 2011. Removal of phosphorus from aqueous solution by Posidonia oceanica fibers using continuous stirring tank reactor. J. Hard Mater. 191, 333-341.

Weber, W.J., Morris, J.C., 1963. Kinetics of adsorption on carbon from solution. J. Sanit. Eng.: Div. Am. Soc. Civ. Eng. 89, 31-60.

Xie, M., Chen, W., Xu, Z., Zheng, S., Zhu, D., 2014. Adsorption of sulfonamides to demineralized pine wood biochars prepared under different thermochemical conditions. Environ. Pollut. 186, 187-194.

Yao, Y., Gao, B., Chen, J., Yang, L., 2012. Engineered biochar reclaiming phosphate from aqueous solutions: mechanisms and potential application as a slow-release fertilizer. Environ. Sci. Technol. 47 (15), 8700-8708.

Yao, Y., Gao, B., Inyang, M., Zimmerman, A.R., Cao, X.D., Pullammanappallil, P., Yang, L.Y., 2011. Removal of phosphate from aqueous solution by biochar derived from anaerobically digested sugar beet tailings. J. Hard Mater. 190 (1-3), 501-507.

Zhang, H., Chen, C., Gray, E.M., Boyd, S.E., Yang, H., Zhang, D., 2016. Roles of biochar in improving phosphorus availability in soils: a phosphate adsorbent and a source of available phosphorus. Geoderma 276, 1-6.

Zhang, J., Liu, J., Liu, R.L., 2015b. Effects of pyrolysis temperature and heating time on biochar obtained from the pyrolysis of straw and lignosulfonate. Bioresour. Technol. 176, 288-291.

Zhang, L., Loaiciga, H.A., Xu, M., Du, C., Du, Y., 2015. Kinetics and mechanisms of phosphorus adsorption in soils from diverse ecological zones in the source area of a drinking-Water Reservoir. Int. J. Environ. Res. Public Health 12, 14312-14326.

Zhao, L., Cao, X., Masek, O., Zimmerman, A., 2013. Heterogeneity of biochar properties as a function of feedstock sources and production temperatures. J. Hard Mater. 19, 256-257. 